\title{
INQUIRY AND POETRY:
}

\section{HAIKU ON AUDIENCE AND PERFORMANCE IN EDUCATION}

Monica Prendergast

Departments of Theatre \& Curriculum and Instruction

University of Victoria

Victoria, BC, Canada

February 10, 2004 


\begin{abstract}
Haiku are presented here as a poetic form of research inquiry that locates researcher stance, bias, and the autobiographical underpinnings of the research process. These research poems also function as examples of ekphrasis, that is, the practice of writing about art objects. In this case, the object of the haiku is the topic of my dissertation study - the development of a curriculum theory (and poetics) for audience in performance.

\section{RÉSUMÉ}

Les haiku sont présentés ici comme une forme d'enquête à base poetique qui situe le point vu, les présuppositions ainsi que l'autobiographie sous-jacente le processus de recherche. Ces poèmes sont aussi des exemples 'd'ekphrasis', - la pratique d'écrire au sujet d'objets d'art. Ici l'objet de haiku, étant le sujet de ma dissertation, sert au développement d'une théorie du curriculum (ainsi que de la poésie) pour l'auditoire lors de représentations.
\end{abstract}




\section{INTRODUCTION}

These poems form part of a current interdisciplinary doctoral inquiry into audience in performance (AIP), particularly theatre audiences, and curriculum. My intention is to place these poems on facing pages throughout my dissertation so that they may reflect upon, play against and perform with the opposing prose text. This aesthetic and intellectual choice is drawn from my belief that the transitory and ephemeral nature and affective experience of performance requires a similar (mimetic) form of writing. Poetic writing about art is called ekphrasis (think of Keats' Ode to a Grecian Urn) and, as such, my dissertation will include ekphrastic writing about audience and performance that interacts, dialogically, with the prose text across from it.

Writing these research poems as haiku was stimulated by a doctoral seminar in education given by Dr. Antoinette Oberg at the University of Victoria in 2003. Dr. Oberg invited her students to synthesize their inquiries into a haiku, based on an essay by Bruce David Russell called "Reaching haiku's pedagogical nature" (2003). In my case, one haiku grew to twenty in the following days. As Russell says,

Haiku position our thoughts to consider the importance of the moment in our lives, and provide a space of reflection for us to consider that we do not access our most memorable experiences in a linear way, but play them out through our continuing emotions and thoughts. (p. 99)

These inquiry haiku have allowed me to better articulate the shape and significance of my topic, to reflect upon my "immediate life experience(s)" (p. 94) as audience member, audience educator and performer, and to play with these moments and memories within the highly constrained form of the haiku. 


\section{HAIKU ON AUDIENCE AND PERFORMANCE IN EDUCATION}

seeing performance

an audience brings itself

into new being

audience presence opens up the performer to the telling tale

audience - aware -

knows its actions make the play applaud themselves too

performance - the space the audience occupies to create meaning

this conversation

between audience and act all stories live here

i perform for you you attend my performance

(no i - no you...we)

you perform for me $i$ attend your performance (no you - no i...we)

what in performance draws the audience to see better who they are?

when the actor speaks

to the audience - what new

dialogues may emerge?

the audience breathes conspiracies of meaning - creates performance 
sharing space and time performer and audience we are complicit

when i act - you see who is the me/not-me you gather in your eyes?

the theatre is a

sacred space - the container of hopes, fears, lies, dreams

who are we when the lights go down? our eyes focus together as one

what is theatre? well -

i have a story to tell attend - that is all

to turn the mind to apply oneself - be present wait upon - escort (Concise Oxford Dictionary)

i want to turn your

mind to performance - to be present - to attend

who goes to the play? "not $i$ " say the young people

"what's on tv?"

how do i transmit

my love of performance to

those who may not care?

within performance lies awareness and presence conditions of form 


\section{REFERENCE}

Russell, B. (2003). Reaching haiku's pedagogical nature. In Hasebe-Ludt, E. \& Hurren, W. (Eds.), Curriculum intertext: Place, language, pedagogy (pp. 93-101). New York: Peter Lang.

\section{RECOMMENDED READING}

Kingston, M.H. (2002). To be the poet. Cambridge, MA: Harvard University Press.

Riechhold, J. (2002). Writing and enjoying haiku: A hands-on guide. Tokyo: Kodansha International

\section{BIOGRAPHY}

Monica Prendergast is an interdisciplinary doctoral student in theatre and curriculum and instruction at the University of Victoria, BC. Her dissertation is a poetic and pedagogic study of audience and performance in education. Recent publications on various aspects of this inquiry are to be found in the Journal of Aesthetic Education, Research in Drama Education, Youth Theatre Journal, Language and Literacy and the Alberta Journal of Educational Research. Monica's Master's thesis, "Imaginative complicity": Audience education and professional theatre (2001), based on her audience education program at Victoria's Belfry Theatre, has led to articles published in Stage of the Art, Drama Contact and the International Journal of Education and the Arts. She has been awarded the American Alliance for Theatre and Education Distinguished Thesis Research Award (August 2003) and the University of Victoria Interdisciplinary Doctoral Fellowship (2003-2005). Monica continues to teach drama and theatre and to direct and perform, all activities in which she has taken much joy over the past twenty years. 